\title{
Growth and Yield Responses of Snap Bean to Mixtures of Carbon Dioxide and Ozone
}

\author{
A. S. Heagle,* J. E. Miller, K. O. Burkey, G. Eason, and W. A. Pursley
}

\begin{abstract}
Elevated $\mathrm{CO}_{2}$ concentrations expected in the 21st century can stimulate plant growth and yield, whereas tropospheric $O_{3}$ suppresses plant growth and yield in many areas of the world. Recent experiments showed that elevated $\mathrm{CO}_{2}$ often protects plants from $\mathrm{O}_{3}$ stress, but this has not been tested for many important crop species including snap bean (Phaseolus vulgaris $\mathrm{L}$.). The objective of this study was to determine if elevated $\mathrm{CO}_{2}$ protects snap bean from $\mathrm{O}_{3}$ stress. An $\mathrm{O}_{3}$-tolerant cultivar (Tenderette) and an $\mathrm{O}_{3}$-sensitive selection (S156) were exposed from shortly after emergence to maturity to mixtures of $\mathrm{CO}_{2}$ and $\mathrm{O}_{3}$ in open-top field chambers. The two $\mathrm{CO}_{2}$ treatments were ambient and ambient with $\mathrm{CO}_{2}$ added for $24 \mathrm{~h} \mathrm{~d}^{-1}$ resulting in seasonal $12 \mathrm{~h} \mathrm{~d}^{-1}(0800-2000 \mathrm{~h}$ EST) mean concentrations of 366 and $697 \mu \mathrm{LL}^{-1}$, respectively. The two $\mathrm{O}_{3}$ treatments were charcoal-filtered air and nonfiltered air with $\mathrm{O}_{3}$ added for $12 \mathrm{~h} \mathrm{~d}^{-1}$ to achieve seasonal $12 \mathrm{~h} \mathrm{~d}^{-1}(0800-2000 \mathrm{~h}$ EST) mean concentrations of 23 and $72 \mathrm{~nL}$ $\mathrm{L}^{-1}$, respectively. Elevated $\mathrm{CO}_{2}$ significantly stimulated growth and pod weight of Tenderette and S156, whereas elevated $\mathrm{O}_{3}$ significantly suppressed growth and pod weight of $\mathrm{S156}$ but not of Tenderette. The suppressive effect of elevated $O_{3}$ on pod dry weight of $\mathrm{S156}$ was approximately $75 \%$ at ambient $\mathrm{CO}_{2}$ and approximately $60 \%$ at elevated $\mathrm{CO}_{2}$ (harvests combined). This amount of protection from $\mathrm{O}_{3}$ stress afforded by elevated $\mathrm{CO}_{2}$ was much less than reported for other crop species. Extreme sensitivity to $\mathrm{O}_{3}$ may be the reason elevated $\mathrm{CO}_{2}$ failed to significantly protect $\mathrm{S156}$ from $\mathrm{O}_{3}$ stress.
\end{abstract}

$\mathrm{C}$ ARBON DIOXIDE $\left(\mathrm{CO}_{2}\right)$ concentrations in the troposphere are expected to continue rising to levels that significantly increase plant growth and yield (Allen, 1990; Cure and Acock, 1986; Kimball et al., 1993; Watson et al., 1990). Conversely, ozone $\left(\mathrm{O}_{3}\right)$ concentrations in the troposphere are high enough to suppress plant growth and yield in many areas of the world (Heck et al., 1984; USEPA, 1996).

Because $\mathrm{O}_{3}$ and $\mathrm{CO}_{2}$ cause opposite plant responses, numerous studies considering effects of $\mathrm{O}_{3}-\mathrm{CO}_{2}$ mixtures have been performed over the past $10 \mathrm{yr}$. Most of these studies revealed that the apparent stimulation caused by $\mathrm{CO}_{2}$ enrichment is much greater when $\mathrm{O}_{3}$ concentrations are also high (Barnes and Pfirrmann, 1992; Heagle et al., 1993, 1998, 1999b; Idso and Idso, 1994; Miller et al., 1998; Mortensen, 1992; Mulchi et al., 1992; Rao et al., 1995; Reinert et al., 1998). Apparently,

A.S. Heagle, J.E. Miller, and K.O. Burkey, USDA-ARS Air QualityPlant Growth and Development Research Unit, 3908 Inwood Road, Raleigh, NC 27603. A.S. Heagle and G. Eason, Dep. of Plant Pathology, J.E. Miller, K.O. Burkey, and W.A. Pursley, Dep. of Crop Science, North Carolina State Univ., Raleigh, NC 27695. Cooperative investigations of the USDA-ARS Air Quality Research Unit and the North Carolina State University. Funded in part by the North Carolina Agricultural Research Service. The use of trade names in this publication does not imply endorsement by the North Carolina Agricultural Research Service or the USDA of the products named, nor criticism of similar ones not mentioned. Received $17 \mathrm{Jan} .2002$. *Corresponding author (asheagle@unity.ncsu.edu).

Published in J. Environ. Qual. 31:2008-2014 (2002).
$\mathrm{CO}_{2}$ protects plants from $\mathrm{O}_{3}$ stress, causing steeper $\mathrm{CO}_{2}$ response curves for plants exposed to stressful $\mathrm{O}_{3}$ levels than for plants exposed to lower $\mathrm{O}_{3}$ levels. Moreover, the level of the interaction seems to be dictated by the relative amount of $\mathrm{O}_{3}$ stress and $\mathrm{CO}_{2}$ enrichment. At a given $\mathrm{O}_{3}$ level, $\mathrm{O}_{3}$-sensitive plants may be more responsive to $\mathrm{CO}_{2}$ enrichment than $\mathrm{O}_{3}$-tolerant plants.

Bean is more sensitive to $\mathrm{O}_{3}$ than many other plant species. Ozone can injure leaves and suppress yield of some popular bean cultivars (Heggestad et al., 1980; Schenone et al., 1992), although some are very tolerant (Meiners and Heggestad, 1979; Davis and Kress, 1974; Tonneijck, 1983). Carbon dioxide enrichment increased net carbon assimilation rate and growth, and decreased stomatal conductance of snap bean (Mjwara et al., 1996; Radoglou and Jarvis, 1992; Radoglou et al., 1992; Tognoni et al., 1967). However, effects of $\mathrm{CO}_{2}$ enrichment on pod weight of snap bean have not been reported. Although seasonal exposure to $\mathrm{O}_{3}-\mathrm{CO}_{2}$ mixtures usually shows that $\mathrm{CO}_{2}$ enrichment protects plants from $\mathrm{O}_{3}$ stress, an exception was shown for snap bean in a shortterm experiment (Heck and Dunning, 1967). Carbon dioxide at approximately $850 \mu \mathrm{L} \mathrm{L}^{-1}$ for $90 \mathrm{~min}$ before and during a $30-\mathrm{min}$ exposure to $300 \mathrm{~nL} \mathrm{~L}^{-1}$ of $\mathrm{O}_{3}$ resulted in significant protection of tobacco (Nicotiana tabacum L. 'Bel-W3') but not 'Pinto' snap bean from foliar injury (Heck and Dunning, 1967). Effects of longterm seasonal exposure to $\mathrm{CO}_{2}$ enrichment or to mixtures of $\mathrm{O}_{3}$ and $\mathrm{CO}_{2}$ on foliar injury, growth, and pod weight of snap bean have not been reported.

Because plant species and cultivars vary in response to elevated $\mathrm{O}_{3}$ and $\mathrm{CO}_{2}$ singly, research to measure interactive effects of $\mathrm{O}_{3}$ and $\mathrm{CO}_{2}$ is needed with additional species. In this study, effects of season-long exposure to mixtures of $\mathrm{O}_{3}$ and $\mathrm{CO}_{2}$ were examined for an $\mathrm{O}_{3}$-tolerant cultivar and an $\mathrm{O}_{3}$-sensitive selection of snap bean in open-top field chambers.

\section{MATERIALS AND METHODS}

\section{Plant Culture}

The experiment was performed with snap bean at our field site $5 \mathrm{~km}$ south of Raleigh, NC. A commercial snap bean cultivar (Tenderette) and a snap bean selection (S156) derived from a cross between the $\mathrm{O}_{3}$-sensitive cultivar (Oregon 91) and the $\mathrm{O}_{3}$-tolerant cultivar (Wade Bush) (Reinert and Eason. 2000 ) were used. Both of these cultigens $(\mathrm{Cg})$ exhibit determinate growth. Tenderette is very resistant to foliar injury caused by $\mathrm{O}_{3}$ (Meiners and Heggestad, 1979), whereas S156 is very sensitive (Burkey and Eason, 2002). Seeds were planted $4 \mathrm{~cm}$ apart in pots containing $20 \mathrm{~L}$ of Metro-Mix 200 and $45 \mathrm{~g}$ of Osmocote (14-14-14, N-P-K) slow release fertilizer (Scotts-

Abbreviations: $\mathrm{CF}$, open-top field chamber receiving charcoal-filtered air; $\mathrm{Cg}$, cultigen, cultivar, or selection of snap bean; NCER, net carbon exchange rate; $\mathrm{OZ}$, open-top field chamber receiving nonfiltered air with $\mathrm{O}_{3}$ added for $12 \mathrm{~h} \mathrm{~d}^{-1} ; \mathrm{SC}$, stomatal conductance. 
Table 1. Meteorological conditions and ozone and carbon dioxide concentrations during studies to determine snap bean response to mixtures of carbon dioxide and ozone.

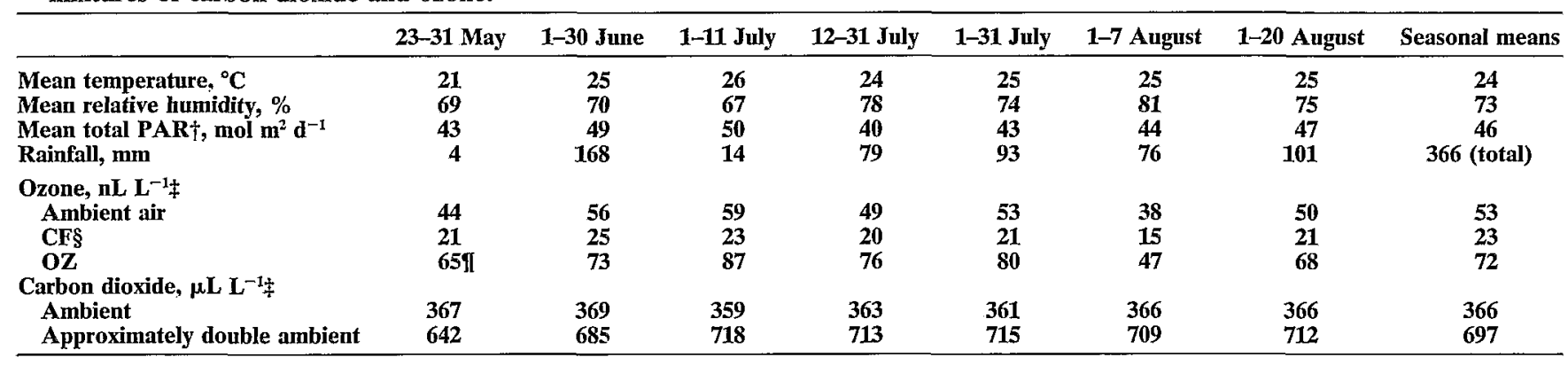

+ Photosynthetically active radiation.

+ Ozone was added to the open-top field chambers receiving nonfiltered air with $\mathrm{O}_{3}$ added for $12 \mathrm{~h} \mathrm{~d}^{-1}$ (0800-2000 $\mathrm{h}$ EST) (OZ). Carbon dioxide was added to double-ambient chambers for $24 \mathrm{~h} \mathrm{~d}^{-1}$. Ozone and carbon dioxide concentrations are 12 h $\mathrm{d}^{-1}(0800-2000 \mathrm{~h}$ EST) means.

$\S$ Open-top field chamber receiving charcoal-filtered air.

II Ozone concentrations for 30-31 May.

Sierra Horticultural Products Co., Marysville, $\mathrm{OH}$ ). Seeds were planted on 15 May and seedlings emerged on 22 May. They were thinned to two per pot on 25 May and to one per pot on 31 May. Plants were irrigated with drip tubes as needed to prevent visible symptoms of water stress. Pot temperatures were moderated with an insulating cylinder composed of 0.6$\mathrm{cm}$-thick bubble wrap coated on both sides with aluminum (Reflectix [Markleville, IN] TM) fit tightly around each pot. This method of temperature moderation has proven more effective than grain straw as a mulch (Heagle et al., 1999a). Thrips were controlled with acephate (Orthene $75 \mathrm{~S}$ at $3.9 \mathrm{~mL}$ $\mathrm{L}^{-1}$; Valent USA Corporation, Walnut Creek, CA) on 26 May and 6 June. Twospotted spider mites were controlled with bifenthrin (Talstar F at $5.2 \mathrm{~mL} \mathrm{~L}^{-1}$; FMC, Philadelphia, PA) and abamectin (Avid $0.15 \mathrm{EC}$ at $0.3 \mathrm{~mL} \mathrm{~L}^{-1}$; Merck \& Co., Rahway, NJ) on 22 July.

\section{Treatments}

Plants were exposed to $\mathrm{O}_{3}$ and $\mathrm{CO}_{2}$ in open-top field chambers, $3 \mathrm{~m}$ in diameter $\times 2.4 \mathrm{~m}$ tall (Heagle et al., 1973). The treatment design was a factorial with two $\mathrm{O}_{3}$ and two $\mathrm{CO}_{2}$ treatments and two snap-bean cultigens. The whole plot (chamber) treatments were the $\mathrm{O}_{3} \times \mathrm{CO}_{2}$ combinations arranged in a randomized complete block design with four blocks in 16 chambers. The $\mathrm{O}_{3}$ treatments were charcoal-filtered (CF) air and nonfiltered air with $\mathrm{O}_{3}$ added proportionally to the ambient $\mathrm{O}_{3}$ concentration $(\mathrm{OZ})$. The $\mathrm{CO}_{2}$ treatments were ambient and approximately double ambient. The two cultigens (Tenderette and S156) were the subplots. Plants were placed in a $2 \times 2$ Latin square arrangement in each of the four chamber quadrants with the convention that two pots of a given cultigen could not be adjacent within a given row or column.

General dispensing and monitoring protocols have been described for $\mathrm{O}_{3}$ (Heagle et al., 1979) and for $\mathrm{CO}_{2}$ (Rogers et al., 1983). Carbon dioxide enrichment began on 23 May and $\mathrm{O}_{3}$ exposures began on 30 May. Exposures continued through 23 August. Ozone was dispensed for $12 \mathrm{~h} \mathrm{~d}^{-1}(0800-2000 \mathrm{~h}$ EST) and $\mathrm{CO}_{2}$ for $24 \mathrm{~h} \mathrm{~d}^{-1}$. Both gases were monitored for $24 \mathrm{~h} \mathrm{~d}^{-1}$ at canopy height in the center of each chamber. Ozone was monitored with UV analyzers (TECO Model 49; Thermo Environmental Instruments, Franklin, MA) calibrated biweekly with a TECO Model 49 PS calibrator. Carbon dioxide was monitored with infrared analyzers (LI 6252; LICOR, Lincoln, NE) calibrated biweekly with pressurized tank $\mathrm{CO}_{2}$ over the range of concentrations used in these experiments. Mean concentrations of $\mathrm{O}_{3}$ and $\mathrm{CO}_{2}$ and meteorological conditions during the experiment are shown in Table 1 . The seasonal mean $12 \mathrm{~h} \mathrm{~d}^{-1} \mathrm{O}_{3}$ concentration in the CF treatment was $23 \mathrm{~nL} \mathrm{~L}^{-1}(0.43$ times ambient), and in the $\mathrm{OZ}$ treatment was $72 \mathrm{~nL} \mathrm{~L}^{-1}$ (1.36 times ambient) (Table 1). The seasonal mean $12 \mathrm{~h} \mathrm{~d}^{-1} \mathrm{CO}_{2}$ concentrations were $366 \mu \mathrm{LL}^{-1}$ (ambient) and $697 \mu \mathrm{L} \mathrm{L}^{-1}$ for the elevated $\mathrm{CO}_{2}$ treatment.

\section{Measurements}

Foliar net carbon exchange rates (NCER) and stomatal conductance (SC) were measured with a portable photosynthesis system (LI-6200; LI-COR). Measures were made at 28, 29.39, and $43 \mathrm{~d}$ after planting (DAP) between 1030 and $1330 \mathrm{~h}$ EST at chamber conditions of relative humidity, temperature,

Table 2. Net carbon exchange rate and stomatal conductance of two snap bean cultigens on four days during exposure to mixtures of ozone and carbon dioxide.

\begin{tabular}{|c|c|c|c|c|c|c|c|c|c|c|}
\hline \multirow[b]{2}{*}{ Cultigen } & \multirow{2}{*}{$\begin{array}{l}\text { Carbon } \\
\text { dioxide } \dagger\end{array}$} & \multirow[b]{2}{*}{ Ozone $\dagger$} & \multicolumn{4}{|c|}{ Net carbon exchange rate $\neq$} & \multicolumn{4}{|c|}{ Stomatal conductance } \\
\hline & & & 28 DAP & 29 DAP & 39 DAP & 43 DAP & 28 DAP & 29 DAP & 39 DAP & 43 DAP \\
\hline & $\mu \mathbf{L} \mathbf{L}^{-1}$ & $\mathbf{n L} \mathbf{L}^{-1}$ & & $-\mu \mathrm{mo}$ & $-2 s^{-}$ & & & - mol & $-2 s^{-1}$ & \\
\hline & & 72 & $21.4(2.2)$ & $21.6(1.0)$ & $11.0(3.7)$ & $6.8(1.6)$ & $1.17(0.07)$ & $1.28(0.15)$ & $0.77(0.33)$ & $0.42(0.06)$ \\
\hline & 697 & 23 & $32.3(0.0)$ & $37.2(0.4)$ & $31.7(2.5)$ & 26.1 (1.5) & $1.15(0.02)$ & $1.38(0.12)$ & $0.51(0.01)$ & $0.59(0.05)$ \\
\hline & & 72 & 31.9 (1.7) & $35.1(2.2)$ & $27.0(4.5)$ & $24.2(1.0)$ & $1.00(0.08)$ & $1.36(0.09)$ & $0.60(0.27)$ & $0.52(0.06)$ \\
\hline Tenderette & 366 & 23 & $23.5(0.4)$ & $23.2(0.5)$ & $12.3(5.4)$ & $11.5(3.6)$ & $1.83(0.03)$ & $1.90(0.23)$ & $0.44(0.28)$ & $0.46(0.23)$ \\
\hline
\end{tabular}

+ Ozone was added to the $72 \mathrm{~nL} \mathrm{L^{-1 }}$ chambers for $12 \mathrm{~h} \mathrm{~d}^{-1}(0800-2000 \mathrm{~h} \mathrm{EST})$. Carbon dioxide was added to $697 \mu \mathrm{L} \mathrm{L}^{-1}$ chambers for $24 \mathrm{~h} \mathrm{~d} \mathrm{~d}^{-1}$. Ozone and carbon dioxide concentrations are seasonal $12 \mathrm{~h} \mathrm{~d}^{-1}(0800-2000 \mathrm{~h}$ EST) means.

\$ DAP, days after planting. Each value is the mean (standard error) for six leaves (one leaf on each of two plants in each of three replicate chambers) at 29 and 43 DAP and four leaves (one leaf on each of two plants in each of two replicate chambers) at 28 and 39 DAP. 


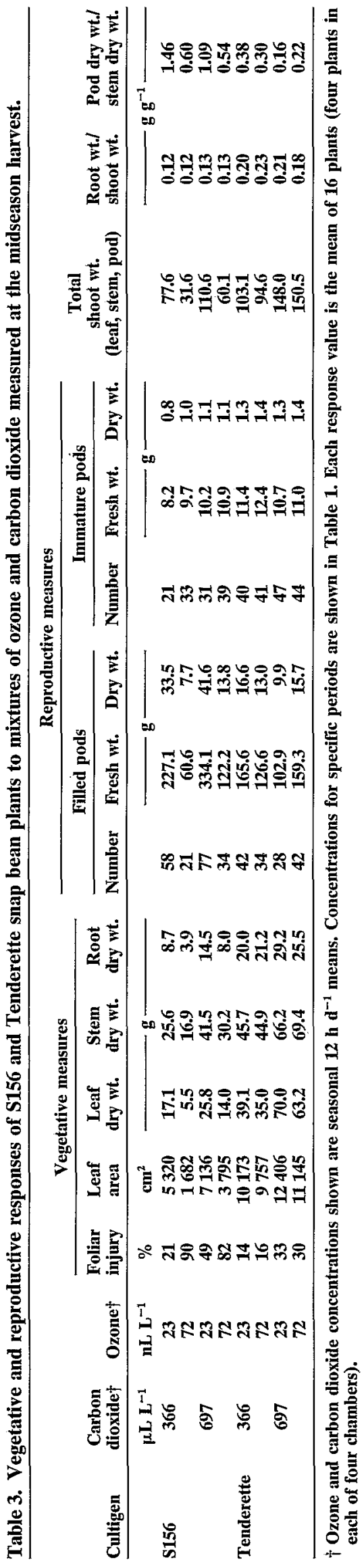

$\mathrm{CO}_{2}$ concentrations, and $\mathrm{O}_{3}$ concentrations when PAR was greater than $1000 \mu \mathrm{mol} \mathrm{m} \mathrm{m}^{-1}$. At each date, one fully expanded upper-canopy leaf (usually the second youngest) from each of two plants per cultigen was sampled for each mixture treatment in each of two plots on 28 and $39 \mathrm{DAP}$ and in each of three plots on 29 and 43 DAP.

At 57 DAP, foliar injury (chlorosis and necrosis) of the upper canopy was estimated in 5\% increments $(0-100 \%)$ on four plants of each cultigen in all plots. Beginning at $57 \mathrm{DAP}$, plants in the south half of each chamber were harvested on four consecutive days. Plants were cut at the stem base and separated into stems, leaves, filled pods (pods with obvious seed expansion), and immature pods (tiny pods with no obvious seed expansion). Leaf areas were measured with a LI3100 area meter (LI-COR). Numbers and fresh weights of filled and immature pods were recorded and roots were washed..Stems, leaves, pods, and roots were dried to constant weight at $55^{\circ} \mathrm{C}$ and weighed.

The remaining eight plants per plot were harvested when most pods were brown and growth was judged to be minimal. The S156 matured sooner than Tenderette, and leaves and pods of S156 plants in the OZ plots turned brown sooner than S156 plants in CF plots. Therefore, S156 plants were harvested between 84 and $86 \mathrm{DAP}$ in the OZ plots and at $98 \mathrm{DAP}$ in the CF plots. Tenderette plants in all plots were harvested between 98 and 101 DAP. Filled and immature pods were counted. Pods and stems were dried to constant weight at $55^{\circ} \mathrm{C}$ and weighed.

\section{Statistical Analyses}

Data were analyzed with the plot (chamber) mean for each cultigen by treatment combination from each block. Because of the large cultigen difference in sensitivity to $\mathrm{O}_{3}$ and exposure duration, data were analyzed for each cultigen separately and for the cultigens combined. Residual plots were examined for nonnormality, outliers, and heterogeneous variances. All variables were analyzed without transformation except for leaf dry weight, which was analyzed with the square-root transformation.

\section{RESULTS}

\section{Net Carbon Exchange Rate and Conductance}

Elevated $\mathrm{CO}_{2}$ increased net carbon exchange rate (NCER) and generally suppressed stomatal conductance (SC) of both cultigens (Table 2). Effects of $\mathrm{O}_{3}$ on NCER and SC varied with the $\mathrm{CO}_{2}$ treatment and was different for the two cultigens. On the last two measurement days, $\mathrm{O}_{3}$ suppressed NCER of S156 in ambient $\mathrm{CO}_{2}$, but less $\mathrm{O}_{3}$ effect was noted with plants at elevated $\mathrm{CO}_{2}$. Little effect of $\mathrm{O}_{3}$ on NCER was noted for Tenderette. Effects of $\mathrm{O}_{3}$ on $\mathrm{SC}$ for both cultigens were variable across measurement dates at both $\mathrm{CO}_{2}$ treatment concentrations.

\section{Midseason Harvest}

Symptoms of $\mathrm{O}_{3}$ injury included chlorosis, bronzing, and early senescence of middle-aged and older leaves, whereas the prominent symptom at elevated $\mathrm{CO}_{2}$ was chlorosis of newly expanded canopy leaves. Ozone caused severe foliar injury of S156 but not of Tenderette, and elevated $\mathrm{CO}_{2}$ significantly injured both cultigens (Tables 3 and 4). For $\mathrm{S} 156$, elevated $\mathrm{CO}_{2}$ caused chloro- 


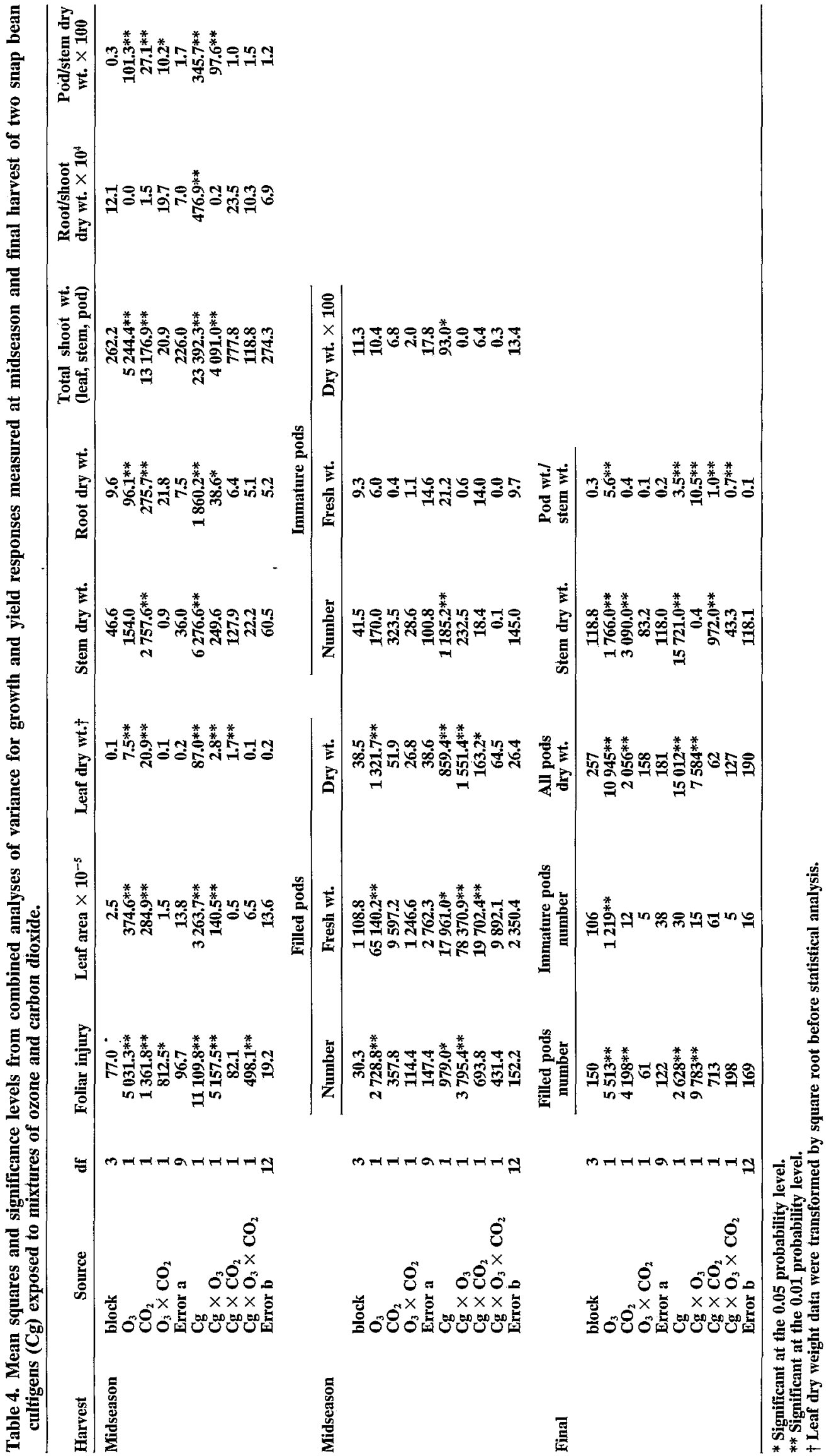


sis in the $\mathrm{CF}$ but not in the $\mathrm{OZ}$ treatments, and $\mathrm{O}_{3}$ caused more injury at ambient than at double-ambient $\mathrm{CO}_{2}$. Either of these differences may have caused the significant $\mathrm{O}_{3} \times \mathrm{CO}_{2}$ interaction for S156 (Table 4).

For $\mathrm{S} 156, \mathrm{O}_{3}$ significantly suppressed all vegetative growth and filled pod measures at both $\mathrm{CO}_{2}$ levels. For example, compared with the $\mathrm{CF}$ treatment, the $\mathrm{OZ}$ treatment suppressed S156 filled pod fresh weight by $73 \%$ in ambient $\mathrm{CO}_{2}$ and by $63 \%$ in elevated $\mathrm{CO}_{2}$. For Tenderette, however, $\mathrm{O}_{3}$ did not significantly affect any measured growth or reproductive component (Table 3) and the $\mathrm{Cg} \times \mathrm{O}_{3}$ interaction was significant for most response measures (Table 4 ).

Carbon dioxide enrichment significantly increased vegetative growth of both cultigens and these effects were generally independent of the $\mathrm{O}_{3}$ treatment (Tables 3 and 4). For the $\mathrm{O}_{3}$ treatments combined, total shoot weight (leaves, stems, and pods) of S156 and Tenderette was 56 and $51 \%$ greater, respectively, at elevated than at ambient $\mathrm{CO}_{2}$ (Table 3). Carbon dioxide enrichment also increased the number and weight of filled pods of S156, but an opposite trend occurred for Tenderette in the CF chambers (Table 3) so that the $\mathrm{Cg} \times \mathrm{CO}_{2}$ effect was significant for filled pod weight (Table 4). For example, in CF air, filled pod dry weight of Tenderette was $40 \%$ less in elevated than in ambient $\mathrm{CO}_{2}$. This trend for lower filled pod weight at elevated than at ambient $\mathrm{CO}_{2}$ did not occur for Tenderette in the OZ chambers (Table 3).

Ratios of pod weight to stem weight were larger for S156 than for Tenderette in all treatments (Table 3). Elevated $\mathrm{CO}_{2}$ significantly decreased the ratio of pod weight to stem weight for both cultigens (Table 3). Elevated $\mathrm{O}_{3}$ decreased pod weight to stem weight for $\mathrm{S} 156$ but not for Tenderette, and the $\mathrm{Cg} \times \mathrm{O}_{3}$ interaction was significant (Table 4 ).

The ratios of root to shoot weight responses of the cultigens were significantly different (Tables 3 and 4). For S156, ratios of root to shoot weight were not affected by $\mathrm{O}_{3}$ or $\mathrm{CO}_{2}$ (Table 3). However, for Tenderette, the ratio of root to shoot weight was higher in $\mathrm{OZ}$ than in $\mathrm{CF}$ at ambient $\mathrm{CO}_{2}$, but was lower in $\mathrm{OZ}$ than in $\mathrm{CF}$ at elevated $\mathrm{CO}_{2}$, and the $\mathrm{O}_{3} \times \mathrm{CO}_{2}$ interaction was significant for Tenderette (Table 3). The high Tenderette root to shoot ratio in $\mathrm{OZ}+$ ambient $\mathrm{CO}_{2}$ was probably related to the comparatively low filled pod weight in that treatment (Table 3).

\section{Final Harvest}

Ozone significantly suppressed filled pod number and pod weight of S156 but not of Tenderette (Table 5), resulting in a significant $\mathrm{Cg} \times \mathrm{O}_{3}$ interaction for these variables (Table 4). Elevated $\mathrm{CO}_{2}$ generally increased pod number, pod weight, and stem weight of both cultigens (Tables 4 and 5). The $\mathrm{CO}_{2}$ effect was significant for these measures in the analysis for the cultigens combined (Table 4) and significant or nearly so for all measures except number of immature pods in the analysis for the cultigens separately (Table 5). The $\mathrm{Cg} \times \mathrm{O}_{3}$, $\mathrm{Cg} \times \mathrm{CO}_{2}$, and $\mathrm{Cg} \times \mathrm{O}_{3} \times \mathrm{CO}_{2}$ interactions were significant for the ratio of pod weight to stem weight (Table 4). Ozone dramatically decreased the ratio of pod weight to stem weight for $\mathrm{S} 156$ but increased the ratio for Tenderette (Table 5). Elevated $\mathrm{CO}_{2}$ decreased the ratio of pod weight to stem weight of Tenderette but not of S156. For S156 in the OZ treatment, the ratio of pod weight to stem weight was higher at elevated than at ambient $\mathrm{CO}_{2}$ (Table 5).

\section{DISCUSSION}

The number and weight of filled pods generally increased between the midseason and final harvest, except for $\mathrm{S} 156$ at ambient $\mathrm{CO}_{2}$ and high $\mathrm{O}_{3}$. In this treatment, $\mathrm{S} 156$ was severely stressed by $\mathrm{O}_{3}$ with estimated visible injury at $90 \%$ at the midseason harvest. This high level of stress apparently caused abscission of immature pods and no increase in number and weight of filled pods between the midseason and final harvest. The decline

Table 5. Growth and reproductive responses of $\$ 156$ and Tenderette snap bean to mixtures of ozone and carbon dioxide at final harvest. $\dagger$

\begin{tabular}{|c|c|c|c|c|c|c|c|}
\hline \multirow[b]{2}{*}{ Cultigen } & \multirow{2}{*}{ Carbon dioxide } & \multirow[b]{2}{*}{ Oxone: } & \multicolumn{2}{|c|}{ Number per plant } & \multicolumn{2}{|c|}{ Dry weight per plant } & \multirow[b]{2}{*}{ Pod wt./stem wt. } \\
\hline & & & Filled pods & Immature pods & All pods & Stems & \\
\hline & $\boldsymbol{\mu} \mathbf{L} \mathbf{L}^{-1}$ & $\mathbf{n} \mathbf{L} \mathbf{L}^{-1}$ & & & & 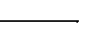 & \\
\hline \multirow[t]{4}{*}{ S156 } & 366 & 23 & 79 & 15 & 75.7 & 22.7 & 3.47 \\
\hline & & 72 & 20 & 0 & 7.5 & 7.2 & 1.05 \\
\hline & 697 & 23 & 114 & 12 & 94.0 & 30.5 & 3.17 \\
\hline & & 72 & 51 & 0 & 26.7 & 16.7 & 1.62 \\
\hline \multirow[t]{5}{*}{ Tenderette } & 366 & 23 & 77 & 12 & 95.0 & 58.6 & 1.70 \\
\hline & & 72 & 78 & 1 & 80.4 & 38.0 & 2.19 \\
\hline & 697 & 23 & 83 & 16 & 99.8 & 83.7 & 1.31 \\
\hline & & 72 & 99 & 5 & 102.0 & 74.2 & 1.45 \\
\hline & Source & df & \multicolumn{5}{|c|}{ Probability of a value $>F$ from analysis of variance } \\
\hline \multirow[t]{4}{*}{$\$ 156$} & block & 3 & 0.84 & 0.30 & 0.59 & 0.08 & 0.40 \\
\hline & $\mathrm{O}_{3}$ & 1 & 0.00 & 0.00 & 0.00 & 0.00 & 0.00 \\
\hline & $\mathrm{CO}_{2}$ & 1 & 0.00 & 0.63 & 0.02 & 0.00 & 0.51 \\
\hline & $\mathrm{O}_{3} \times \mathrm{CO}_{2}$ & 1 & 0.72 & 0.63 & 0.94 & 0.65 & 0.05 \\
\hline \multirow[t]{4}{*}{ Tenderette } & block & 3 & 0.16 & 0.10 & 0.07 & 0.79 & 0.12 \\
\hline & $\mathrm{O}_{3}$ & 1 & 0.18 & 0.00 & 0.33 & 0.09 & 0.04 \\
\hline & $\mathrm{CO}_{2}$ & 1 & 0.05 & 0.11 & 0.06 & 0.00 & 0.00 \\
\hline & $\mathrm{O}_{3} \times \mathrm{CO}_{2}$ & 1 & 0.23 & 0.99 & 0.20 & 0.50 & 0.21 \\
\hline
\end{tabular}

$\uparrow$ Each response value is the mean of 16 plants (four plants in each of four chambers).

$\div$ Ozone and carbon dioxide concentrations shown are seasonal $12 \mathrm{~h} \mathrm{~d}^{-1}$ means. Concentrations for specific periods are shown in Table 1 . 
in stem weight between the midseason and final harvest, especially for $\mathrm{S} 156$ at high $\mathrm{O}_{3}$, can be explained by translocation of assimilate and respiration, which usually accompanies plant senescence.

Elevated $\mathrm{CO}_{2}$ was much less protective against $\mathrm{O}_{3}$ stress in the highly $\mathrm{O}_{3}$-sensitive snap bean cultigen $\mathrm{S} 156$ than for any of the other crops studied. For example, in one year with soybean, $\mathrm{O}_{3}$ yield suppression was $37 \%$ at ambient $\mathrm{CO}_{2}$, but was negligible at double-ambient $\mathrm{CO}_{2}$ (Heagle et al., 1998). In a second season, $\mathrm{O}_{3}$ decreased soybean yield by $40 \%$ at ambient $\mathrm{CO}_{2}$ and by $16 \%$ at double-ambient $\mathrm{CO}_{2}$ (Heagle et al., 1998). Similar results were found with cotton (Heagle et al., 1999b) and with an $\mathrm{O}_{3}$-sensitive cultivar of wheat (Heagle et al., 2000). In the present study, however, doubled $\mathrm{CO}_{2}$ provided very little protection against severe $\mathrm{O}_{3}$ suppression of pod yield for S156, even though exposure to elevated $\mathrm{CO}_{2}$ alone stimulated pod yield by $24 \%$. For Tenderette, however, doubled $\mathrm{CO}_{2}$ completely prevented the already less severe pod yield suppression $(15 \%)$ due to $\mathrm{O}_{3}$. It appears that the extreme sensitivity to $\mathrm{O}_{3}$ in $\mathrm{S} 156$ overwhelmed what protection elevated $\mathrm{CO}_{2}$ might have provided.

The present results do not adequately show whether differences in effects of elevated $\mathrm{CO}_{2}$ on stomatal conductance account for differences in the protective effects of elevated $\mathrm{CO}_{2}$ among species. The maximum decrease in stomatal conductance of $\mathrm{S} 156$ caused by elevated $\mathrm{CO}_{2}$ was approximately $30 \%$, whereas elevated $\mathrm{CO}_{2}$ decreased stomatal conductance of soybean by approximately $40 \%$ (J.E. Miller, personal communication, 2001). Further research is needed to determine the degree to which differences in $\mathrm{CO}_{2}$ effects on stomatal conductance are related to differential levels of $\mathrm{CO}_{2}$ protection from $\mathrm{O}_{3}$ stress.

Our results confirmed the difference in $\mathrm{O}_{3}$ sensitivity of the two cultigens. Under the exposure conditions employed, elevated $\mathrm{O}_{3}$ suppressed the bean yield of sensitive S156 by 80 to $90 \%$, but did not significantly affect the yield of tolerant Tenderette. The basis for this difference in $\mathrm{O}_{3}$ response does not appear to involve $\mathrm{O}_{3}$ exclusion. A cultigen comparison of midday $\mathrm{SC}$ for each date $X$ treatment combination (Table 2) revealed very few cases where S156 and Tenderette were different, and where differences were observed there was no trend to suggest that $\mathrm{O}_{3}$ uptake was greater in S156. Overall, cultigen differences in SC were small compared with the large difference in $\mathrm{O}_{3}$ effect on yield. Studies are planned to determine whether a subtle difference in leaf gas exchange (e.g., diurnal pattern, stomata response to environmental factors) might explain the observed differences in $\mathrm{O}_{3}$ sensitivity. Differences in cultigen detoxification of $\mathrm{O}_{3}$ in the leaf interior may explain the differential sensitivity. This hypothesis is supported by recent observations that extracellular ascorbic acid content is significantly higher in tolerant Tenderette than in sensitive S156 (Burkey and Eason, 2002).

Prior to the present study, experimental evidence strongly suggested that elevated $\mathrm{CO}_{2}$ protects $\mathrm{O}_{3}$-sensitive plants from $\mathrm{O}_{3}$ stress. Such protection generally resulted in greater growth and yield enhancement for
$\mathrm{O}_{3}$-sensitive than for $\mathrm{O}_{3}$-tolerant plants. The present study shows that protection from $\mathrm{O}_{3}$ stress is not necessarily controlled by relative sensitivity to $\mathrm{O}_{3}$, by the $\mathrm{O}_{3}$ concentration, or by relative response to $\mathrm{CO}_{2}$ enrichment. The degree of $\mathrm{O}_{3} \times \mathrm{CO}_{2}$ interaction for a given species or cultivar cannot be predicted from response to the individual gases. These results emphasize the need to understand interactive effects between $\mathrm{O}_{3}$ and $\mathrm{CO}_{2}$ on yield of major food crops to improve estimates of crop yield at $\mathrm{CO}_{2}$ concentrations expected in the future.

\section{ACKNOWLEDGMENTS}

We thank Bob Philbeck, Fred Mowry, and Jeff Barton for dispensing and monitoring support and Bianca Bradford, Julie Clingerman, Josh Collins, James Jackson, Robin Randall, Aminah Thompson, and Renee Tucker for technical support and Barbara Shew and Steve Shafer for manuscript review.

\section{REFERENCES}

Allen, L.H. 1990. Plant responses to rising carbon dioxide and potential interactions with air pollutants. J. Environ. Qual. 19:15-34.

Barnes, J.D., and T. Pfirrmann. 1992. The influence of $\mathrm{CO}_{2}$ and $\mathrm{O}_{3}$, singly and in combination, on gas exchange, growth and nutrient status of radish (Raphanus sativus L.). New Phytol. 121:403-412.

Burkey, K.O., and G. Eason. 2002. Ozone tolerance in snap bean is associated with elevated ascorbic acid in the leaf apoplast. Physiol. Plant. 114:387-394.

Cure, J.D., and B. Acock. 1986. Crop responses to carbon dioxide doubling: A literature survey. Agric. For. Meteorol. 38:127-145.

Davis, D.D., and L. Kress. 1974. The relative susceptibility of ten bean varieties to ozone. Plant Dis. Rep. 58:14-16.

Heagle, A.S., D.E. Body, and W.W. Heck. 1973. An open-top field chamber to assess the impact of air pollution on plants. J. Environ. Qual. 2:365-368.

Heagle, A.S., F.L. Booker, J.E. Miller, E.L. Fiscus, W.A. Pursley, and L.A. Stefanski. 1999a. Influence of daily carbon dioxide exposure duration and root environment on soybean response to elevated carbon dioxide. J. Environ. Qual. 28:666-675.

Heagle, A.S., J.E. Miller, F.L. Booker, and W.A. Pursley. 1999b. Ozone stress, carbon dioxide enrichment, and nitrogen fertility interactions in cotton. Crop Sci. 39:731-741.

Heagle, A.S., J.E. Miller, and W.A. Pursley. 2000. Effects of ozone and carbon dioxide interactions on growth and yield of winter wheat. Crop Sci. 40:1656-1664.

Heagle, A.S., J.E. Miller, W.A. Pursley, and F.L. Booker. 1998. Influence of ozone stress on soybean response to carbon dioxide enrichment: III. Yield and seed quality. Crop Sci. 38:128-134.

Heagle, A.S., J.E. Miller, D.E. Sherrill, and J.O. Rawlings. 1993. Effects of ozone and carbon dioxide mixtures on two clones of white clover. New Phytol. 123:751-762.

Heagle, A.S., R.B. Philbeck, H.H. Rogers, and M.B. Letchworth. 1979. Dispensing and monitoring $\mathrm{O}_{3}$ in open-top field chambers for plant effects studies. Phytopathology 69:15-20.

Heck, W.W., W.W. Cure, J.O. Rawlings, L.J. Zaragoza, A.S. Heagle, H.E. Heggestad, R.J. Kohut, L.W. Kress, and P.J. Temple. 1984. Assessing impacts of ozone on agricultural crops: I. Overview. J. Air Pollut. Control Assoc. 34:729-735.

Heck, W.W., and J.A. Dunning. 1967. The effects of ozone on tobacco and pinto bean as conditioned by several ecological factors. J. Air Pollut. Control Assoc. 17:112-114.

Heggestad, H.E., A.S. Heagle, J.H. Bennett, and E.J. Koch. 1980. The effects of photochemical oxidants on the yield of snap beans. Atmos. Environ. 14:317-326.

Idso, K.E., and S.B. Idso. 1994. Plant responses to atmospheric $\mathrm{CO}_{2}$ enrichment in the face of environmental constraints: A review of the past 10 years research. Agric. For. Meteorol. 69:153-203.

Kimball, B.A., J.R. Mauney, F.S. Nakayama, and S.B. Idso. 1993. Effects of increasing atmospheric $\mathrm{CO}_{2}$ on vegetation. Vegetatio 104:65-75.

Meiners, J.P., and H.E. Heggestad. 1979. Evaluation of snap bean 
cultivars for resistance to ambient oxidants in field plots and to ozone in chambers. Plant Dis. Rep. 63:273-277.

Miller, J.E., A.S. Heagle, and W.A. Pursley. 1998. Influence of ozone stress on soybean response to carbon dioxide enrichment: II. Biomass and development. Crop Sci. 38:122-128.

Mjwara, J.M., C.E.J. Botha, and S.E. Radloff. 1996. Photosynthesis, growth and nutrient changes in non-nodulated Phaseolus vulgaris grown under atmospheric and elevated carbon dioxide conditions. Physiol. Plant. 97:754-763.

Mortensen, L.M. 1992. Effects of ozone concentration on growth of tomato at various light, air humidity and carbon dioxide levels. Sci. Hortic. (Amsterdam) 49:17-24.

Mulchi, C.L., L. Slaughter, M. Saleem, E.H. Lee, R. Pausch, and R. Rowland. 1992. Growth and physiological characteristics of soybean in open-top chambers in response to ozone and increased atmospheric $\mathrm{CO}_{2}$. Agric. Ecosyst. Environ. 38:107-118.

Radoglou, K.M., P. Aphalo, and P.G. Jarvis. 1992. Response of photosynthesis, stomatal conductance and water use efficiency to elevated $\mathrm{CO}_{2}$ and nutrient supply in acclimated seedlings of $P$ haseolus vulgaris L. Ann. Bot. (London) 70:257-264.

Radoglou, K.M., and P.G. Jarvis. 1992. Effects of $\mathrm{CO}_{2}$ enrichment and nutrient supply on growth and leaf anatomy of Phaseolus vulgaris L. seedlings. Ann. Bot. (London) 70:245-256.

Rao, M.V., B.A. Hale, and D.P. Ormrod. 1995. Amelioration of ozoneinduced oxidative damage in wheat plants grown under high carbon dioxide. Plant Physiol. 109:421-432.
Reinert, R.A., and G. Eason. 2000. Genetic control of $\mathrm{O}_{3}$ sensitivity in a cross between two cultivars of snap bean. J. Am. Soc. Hortic. Sci. 125:222-227.

Reinert, R.A., G. Palmer, and J. Barton. 1998. Growth and fruiting of tomato as influenced by elevated carbon dioxide and ozone. New Phytol. 137:411-420.

Rogers, H.H., W.W. Heck, and A.S. Heagle. 1983. A field technique for the study of plant responses to elevated carbon dioxide concentrations. J. Air Pollut. Control Assoc. 33:42-44.

Schenone, G., G. Botteschi, I. Fumigalli, and F. Montinaro. 1992. Effects of ambient air pollution in open-top chambers on bean (Phaseolus vulgaris L.). 1. Effects on growth and yield. New Phytol. 122:689-697.

Tognoni, F., A.H. Halevy, and S.H. Wittwer. 1967. Growth of bean and tomato plants as affected by root absorbed growth substances and atmospheric carbon dioxide. Planta 72:43-52.

Tonneijck, A.E.G. 1983. Foliar injury response of 24 bean cultivars (Phaseolus vulgaris) to various concentrations of ozone. Neth. J. Plant Pathol. 89:99-104.

USEPA. 1996. Air quality criteria for ozone and related photochemical oxidants. EPA/600-90/004bF. Natl. Center for Environ. Assessment, Office of Res. and Development, Research Triangle Park, NC.

Watson, R.T., H. Rodhe, H. Oeschegerm, and U. Siegenthaler. 1990. Greenhouse gases and aerosols. p. 1-44. In T.J. Houghton, G.J. Jenkins, J.J. Ephraums (ed.) Climate change. The IPCC scientific assessment. Cambridge Univ. Press, Cambridge. 


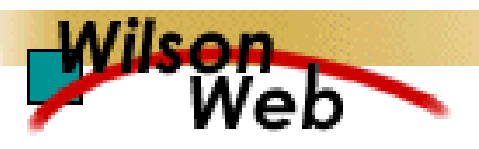

\section{COPYRIGHT INFORMATION}

TITLE: Growth and Yield Responses of Snap Bean to Mixtures of Carbon Dioxide and Ozone

SOURCE: Journal of Environmental Quality 31 no6 N/D 2002

WN: 0230502385028

The magazine publisher is the copyright holder of this article and it is reproduced with permission. Further reproduction of this article in violation of the copyright is prohibited. To contact the publisher:

http://www.agronomy.org/.

Copyright 1982-2003 The H.W. Wilson Company. All rights reserved. 